\title{
PAULA STRADIṆA BALVAS LAUREĀTI 1999. UN 2000. GADĀ
}

Paula Stradina Medicīnas vēstures muzejs, godinot savu dibinātāju Paulu Stradinuu (1896-1958), 1983. gadā nodibināja Paula Stradiṇa balvu. Balvas piešķiršanas nolikumu Latvijas PSR Veselības aizsardzības ministrija apstiprināja 1983. gada 5. janvārī. Saskaṇā ar to ikgadējā balva pieškirama autoram vai autoru kolektīvam par izcilu medicīnas vai farmācijas vēstures pētījumu (monogrāfija, publikāciju kopa, muzeja ekspozīcija). Pirmoreiz balvu piešḳīra par 1982.gadu un pasniedza 1983. gada 1. februārī diviem laureātiem - Vilhelmam Kaņepam un Jānim Stradiñam par ieguldījumu medicīnas vēstures attīstībā un Paula Stradiṇa Medicīnas vēstures muzeja zinātniskās koncepcijas izveidi.

Kopš 1992. gada Paula Stradina Medicīnas vēstures muzejs balvu pieškir kopā ar Latvijas Zinātṇu akadēmij par izcilu darbu medicīnas zinātnē vai pētījumu medicīnas vēsturē (to pieškir reizi gadā - medicīnā vai medicīnas vēsturē). Līdz 2000. gadam balva piešķirta 30 zinātniekiem.

Paula Stradina balvu veidojis tēlnieks Jānis Strupulis. Tā ir divpusējs 24,5 x 10 $\mathrm{cm}$ liels bronzas reljefs, kas piestiprināts koka pamatnei un novietojams uz galda. Aversā attēlots mītiskais sengrieķu dievs Asklēpijs ar zizli, ap kuru apvijusies čūska, lejpusē teksts "Praemium Pauli Stradini". Reversa augšda|ā Paula Stradina portrets profilā, ko lokveidā apvij teksts "Museum Historiae Medicinae Pauli Stradini nominatum", lejasdalā medicīnas simbols - čūska, bet vidusda|ā tiek iegravēts laureāta vārds un apbalvošanas gadskaitlis, zemāk atbilstoša prātula latīṇu valodā. Balvu pasniedz kopā ar diplomu latīṇu valodā.

1999.gada 12.janvārī notika Latvijas Medicīnas akadēmijas Medicīnas vēstures institūta un Paula Stradina Medicīnas vēstures muzeja Zinātniskās padomes sēde, kurā Paula Stradiṇa balvu par pētījumiem medicīnas vēsturē 1999. gadā ar balsu vairākumu no pieciem kandidātiem piešķ̄̄ra diviem zinātniekiem Oslo universitātes profesoram Eivindam Larsenam un bijušajam rīdziniekam profesoram Zelikam Čerfasam, kas no 1990. gada dzīvo Izraēlā.

2000. gadā Paula Stradiṇa balvu pieškīra ASV dzīvojošam latviešu izcelsmes ārstam profesoram Jānim Klaviṇam. 


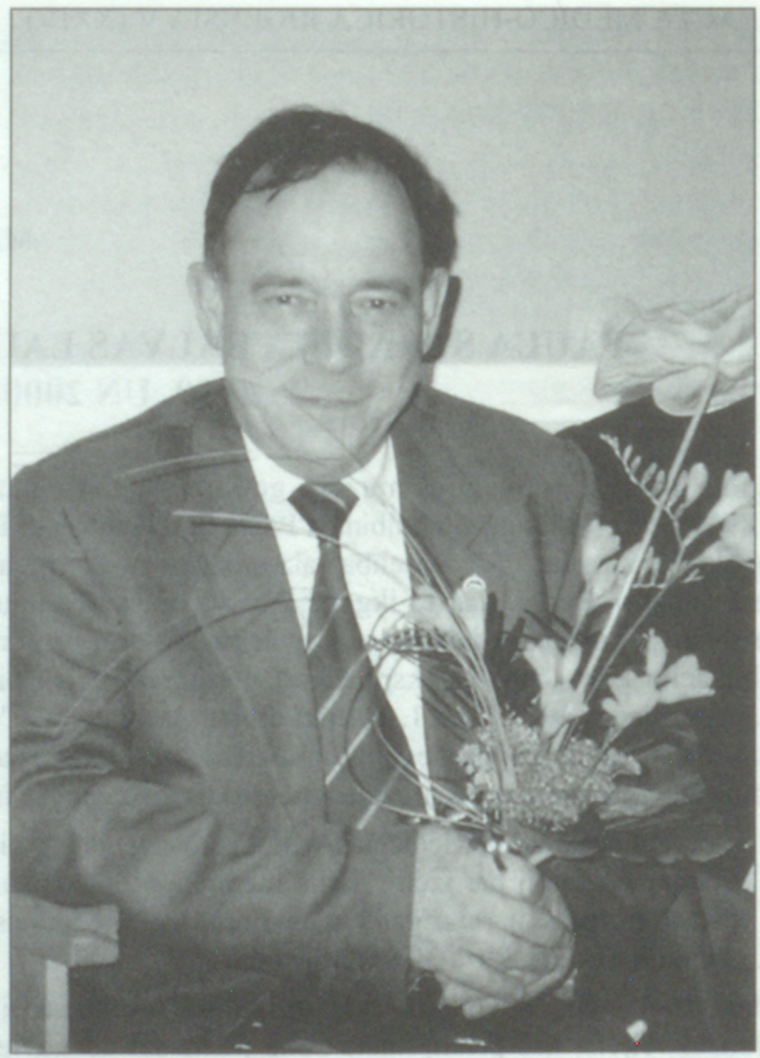

Profesors Eivinds Larsens (Øivind Larsen)

Profesoram E. Larsenam Paula Stradiṇa balva piešķirta par medicīnas vēsturnieku un Paula Stradiṇa Medicīnas vēstures muzeja starptautisko sakaru veicināšanu.

Eivinds Larsens dzimis 1938. gada 6. septembrī Oslo. 1962. gadā ieguvis ārsta grādu Oslo universitātē, 1970. gadā ievēlēts par asociēto profesoru medicīnas vēsturē, 1976. gadā par profesoru veselības aizsardzībā Tromso universitẫtē Zieme|norvēgeijā. No 1985. gada E. Larsens ir profesors medicīnas vēsturē Oslo universitātē, bet kopš 1993. gada - Oslo universitātes Vispārējās prakses un komunālās medicīnas institūta vadītājs; 1991. gadā iecelts par Norvēǵijas Zinātṇu akadēmijas locekli.

Profesors E. Larsens daudzkārt viesojies Latvijā, organizējis starptautiskus praktiskus seminārus Rīgā, ir šā krājuma redkolēgijas loceklis. 


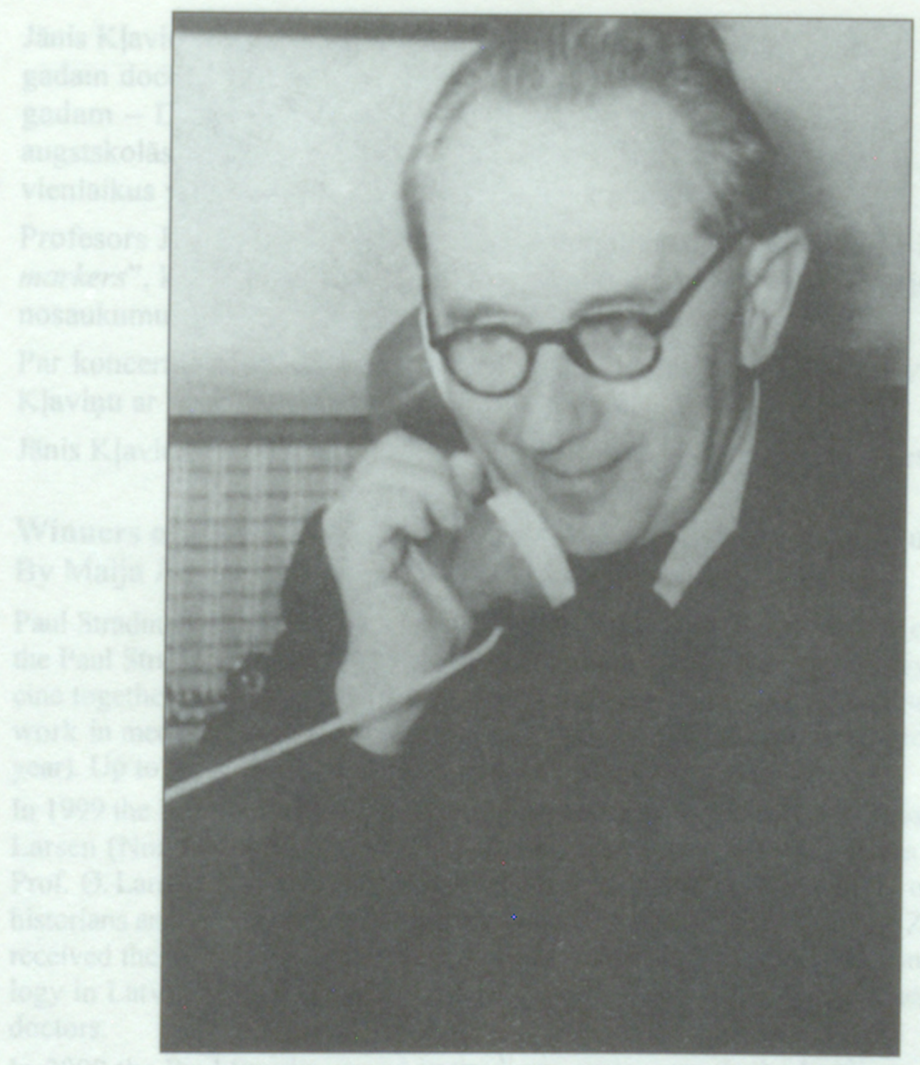

Profesors Zeliks Čerfass

Prof. Zelikam Čerfasam Paula Stradiṇa balva piešķirta par darbiem Latvijas medicīnas vēsturē un deontologijāa, kā arī par nopelniem vairāku paaudžu ārstu izglîtošanā.

Z. Čerfass dzimis 1911. gada 21. februārī N̦ižnijnovgorodā. Ārsta grādu ieguvis Latvijas Universitātē 1935. gadā, strādājis par iekšḳīgo slimību ârstu Rīgā, bijis Rīgas Medicīnas institūta docētājs no 1952. līdz 1989. gadam. 1973. gadā ieguvis medicīnas zinātnu doktora grādu.

1990. gadā profesors Zeliks Čerfass pārcēlies uz dzīvi Izraēlā.

Prof. Z. Čerfass publicējis vairākas grāmatas; dzīves atziṇas apkopotas grāmatā "Pie slimnieka gultas", kas izdota 1990. gadā Rīgā.

1992. gadā profesors Zeliks Čerfass ievēlēts par Latvijas Ārstu biedrības goda biedru. 


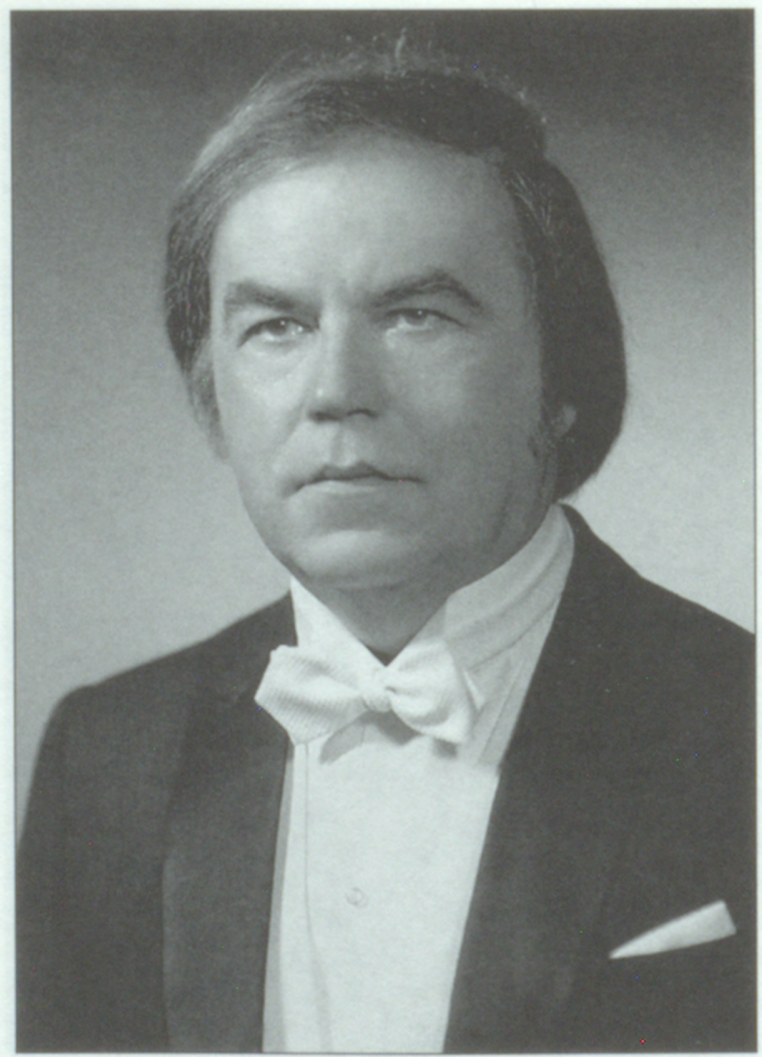

Profesors Jānis Klavin̨̧

Par Paula Stradina balvas laureātu medicīnā 2000. gadā Latvijas Zinātṇu akadēmija izraudzija Amerikas Savienotajās Valstīs dzīvojošo onkologu Jāni Klaviṇu - Latvijas Zinātṇu akadēmijas ārzemju locekli, Bruklinas Queen Medicīnas centra patoloǵijas departamenta emeritētu profesoru.

Profesoram Jānim KJaviņam Paula Stradiṇa balva piešķirta par nozīmīgiem pētījumiem onkologijā un ieguldījumu Latvijas medicīnas attīstībā. Balvu profesors Jānis Klaviṇš saṇēma Paula Stradiṇa Medicīnas vēstures muzejā 37. Stradiṇa lasījumu laikā 2000. gada 27. janvārī, nolasot akadēmisko runu "Xenopus laevis un laundabīgo audzēju kopējie onkofetālie antigēni".

Jānis Klaviṇš dzimis 1921. gada 6. maijā Abrenes apriṇķa Rugājos. 1941. gadā uzsācis medicīnas studijas Latvijas Universitātē. 1948. gadā ieguvis ărsta grădu Vācijā, Kīiles universitātē. Vienlaikus studējis dziedāšanu Lībekas mūzikas akadēmijā. 
Jānis KJaviṇš bijis mācỉbspēks vairākās ASV augstskolās - no 1954. līdz 1960. gadam docētājs Rietumu rezerves universitātē Klīvlendā, no 1960. līdz 1965. gadam - Djūka universitātē Daremā, pēcāk profesors vairākās N̦ujorkas augstskolās. Kopš 1985. gada J. Klaviṇš bijis Kornela universitātes profesors, vienlaikus vadījis slimnīcu patologijas departamentus.

Profesors J. Klaviṇš sarakstịjis vairākas publikācijas, nozīmīgākā ir "Tumor markers”, kas izdota 1986. gadā N̦ujorkā. Ieguvis daudzus akadēmiskos goda nosaukumus.

Par koncertdziedoṇa panākumiem Vīnes Šūberta akadēmija apbalvojusi Jāni K|aviņu ar lielo zelta meda|u.

Jānis Klaviṇš iedziedājis kompaktdiskos visas Jāzepa Vītola solodziesmas.

\section{Winners of Paul Stradin Prize in the Years 1999 and 2000 (Summary) By Maija Anže}

Paul Stradin Museum of the History of Medicine, in honor of its founder established the Paul Stradin Prize. Since 1992 the Paul Stradin Museum of the History of Medicine together with Latvia's Academy of Science awards the prize for outstanding work in medical science or research in the history of medicine (it is awarded once a year). Up to the year 2000 the prize was awarded to 30 scientists.

In 1999 the Paul Stradin award in history of medicine was given to Professor Øivind Larsen (Norway) and Professor Zeliks Cherfass, who since 1990 lives in Israel. Prof. Ø. Larsen received the award for furthering the international links of medical historians and the Paul Stradin Museum of the History of Medicine. Prof. Z.Cherfass received the Paul Stradin Prize for his works in the history of medicine and deontology in Latvia, as well as for his merits in the education of several generations of doctors.

In 2000 the Paul Stradin award in medicine was given to the Latvian oncologist Jānis KJavin̨š, who is living in the USA. He is foreign member of Latvia's Academy of Science and emerited professor of Brooklin's Queen medical center pathology department. Prof. J. Klaviñs was awarded the Paul Stradin Prize for important research in oncology and his investment into the development of Latvia's medicine.

Maija Anže, Mag. hist.

Paula Stradina Medicīnas vēstures muzejs

Antonijas iela 1, LV 1360, Rīga, Latvia

E-mail: museum3@mailbox.riga.lv 


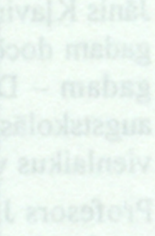

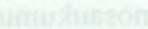

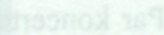

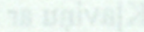

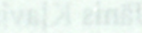

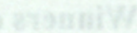

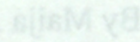

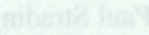

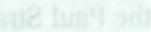

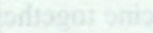

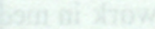

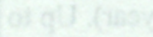

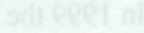

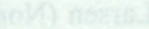

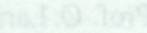

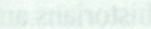

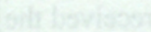

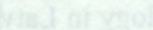

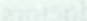

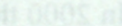

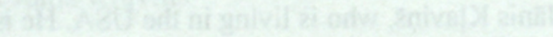

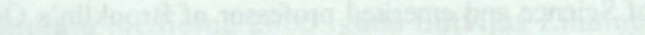

